ECONOMICS

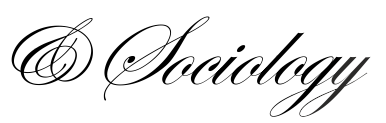

\section{Ladislav Vagner}

University of Zilina, Faculty of

Operation and Economics of

Transport and Communications,

Slovakia

E-mail:

ladislav.vagner@fpedas.uniza.sk

Katarina Valaskova

University of Zilina, Faculty of

Operation and Economics of

Transport and Communications,

Slovakia

E-mail:

katarina.valaskova@,ppedas.uniza.sk

\section{Pavol Durana}

University of Zilina, Faculty of

Operation and Economics of

Transport and Communications,

Slovakia

E-mail:

pavol.durana@,fpedas.uniza.sk

\section{George Lazaroiu}

Spiru Haret University,

Faculty of Economic Sciences,

Bucharest, Romania

E-mail:phd lazaroin@yahoo.com

Received: March, 2020

1st Revision: July, 2020

Accepted: March, 2021

DOI: $10.14254 / 2071-$

789X.2021/14-1/16

JEL Classification: G00, M20, M41
Vagner, L., Valaskova, K., Durana, P., \& Lazaroiu, G. (2021). Earnings

management: A bibliometric analysis. Economics and Sociology, 14(1), 249-262.

doi:10.14254/2071-789X.2021/14-1/16

\section{EARNINGS MANAGEMENT: A BIBLIOMETRIC ANALYSIS}

ABSTRACT. This research paper aims to analyse the keywords related to earnings management issues and then to focus on their evolution and changes in decades - from 1988, when the first publication about this issue appeared in the Web of Science, to the present. When examining literature concerning the analysis of keywords and their development using bibliometric analysis, a similar publication was not found. Therefore, it is an original and exciting publication that clarifies the work with the keywords on the selected topic and strictly within the articles available in the Web of Science database. In total, 1.547 articles on earnings management were analysed. The authors used analysis to assess individual articles, synthesis - to link context, statistical procedures - to select the keywords using the functions available in Excel, and VOS viewer to present visually the results of the analysed keywords. At the same time, this division allowed monitoring changes before and after the global financial crisis. The changes were most influenced by global trends and overall publication growth in the world. The only term most commonly associated with earnings management in all the periods is accruals. By demonstrating the formation of the terms used, the determined goal - to find out a significant change in the development of the keywords within the earnings management in the time horizon was met. In the future, it would be interesting to follow developments in the coming years of the decade and to see changes in the use of earnings management influenced by the recent global events.

Keywords: earnings, earnings manipulation, literature review, bibliometrics. 


\section{Introduction}

Earnings management (or profit management) can be considered as the uses of various accounting techniques, the main purpose of which is to prepare financial statements in such a way that the business activity of a company, as well as its financial situation, is rendered in the most positive light. Many accounting policies and principles require business managers to make their decisions for this purpose. Therefore, earnings management monitors how accounting policies can be used and financial statements produced to increase or offset business income. The optimal capital structure connected with earnings management is the key precondition for business, even though defining the optimal capital structure is difficult (Belas, 2018).

This research paper aims to analyse the keywords related to earnings management issues and then to focus on their evolution and changes over some time, from 1988 to the present. When examining the literature concerning the analysis of keywords and their development using bibliometric analysis, a similar publication was not found, thus, this application is of particular benefit to the scientific community, namely, theoreticians and researchers. Therefore, it is an original and exciting publication that clarifies the work with the keywords on the selected topic.

The research paper consists of five chapters. The first chapter, Introduction, explains the aim of the work, focus and originality of the article. In the second chapter, Theoretical background, necessary information about earnings management is provided along with a detailed overview of the authors dealing with this field. In the third chapter the research objective is described, the methodology used and the method of data collection. In the next chapter, the results of the bibliometric analysis are described. In the last section, the results and achievement of the set goal are summarized.

The output of this paper points out how perceptions change as well as the application of earnings management in specific reporting periods (decades). It is essential to be aware of all the changes associated with earnings management. At the same time, this study can be beneficial for all those who deal with this area, whether it's academic community members or managers deciding on the earnings.

\section{Literature review}

Earnings management is a complex phenomenon that has been studied by authors in many publications. As reported by Healy (1985), earnings management serves to achieve stable and predictable financial results. Earnings management assists in achieving specific discretionary accrual handling objectives. In addition to accrual-based earnings management, professional literature also distinguishes between real earnings management, which is typically influenced by corporate cash flow Kramarova et al. (2014). Earnings management has a significant effect especially, on corporate economic performance, bankrupt or financial health as a whole (Grofcikova, 2020; Fialova \& Folvarcna, 2020).

There is extensive publication activity on the impact of earnings management on the capital market. The idea of economic profit is based on the existence of opportunity Salaga, et al. (2015). Earnings management usually does not mislead investors, instead it provides useful information supporting correct financial decisions. Current revenue, which reflects management's judgment, is value-relevant and is a better predictor of future cash flow performance compared to present cash flows. Evidence of share returns also suggests that investors discount unusual gains compared to regular gains, indicating that they consider anomalous gains more likely to reflect manipulation with earnings (Healy, 1999). 
Beneish (2001) compared three definitions of earnings management used by accountants in his publication. It also deals with three estimation methods. These are cumulative incremental methods, namely increments and discontinuities, in the distribution of earnings. It discusses the reasons for earnings-increasing earnings management, earnings-reducing earnings management, and the specific context, e.g. financial institutions with regulatory constraints. Despite the limited evidence, managers are more likely to manipulate income rather than up. McNichols (2000) also dealt with these three procedures. In earnings management, she discussed the characteristics of the three most commonly used designs. These are aggregate accrual models, specific accrual models and access to frequency distribution. One of the main arguments against the use of aggregated accrual models is that they do not have enough knowledge of how these accruals behave in the absence of earnings management, which is why McNichols has argued that progress in earnings management research would come from specific accruals. In her publications, the critical issue is that empirical approaches for cumulative accrual studies are lagging behind stimulus theories for managing accrual control, as well as institutional knowledge of accrual behaviour. Empirical findings suggest that aggregated accrual models that do not take into account long-term earnings growth are potentially misspelt and may lead to misleading conclusions about earnings behaviour. Hardingham, et al. (2018). It, therefore, indicates that next advancement in the literature on earnings management seems to be focused on the application of specific accrual and distribution tests rather than cumulative accrual tests. A similar issue is investigated by Sosnowski (2018).

The prognosis of earnings management was discussed by Hirst et al. (2008), categorizing earnings predictions by three different subsets (antecedents, characteristics, and consequences) that correspond to the timeline associated with earnings forecasts. They concluded that most of the previous research focuses on how one prediction or prediction characteristic affects predictions and does not investigate potential interactions between the three components. They have also concluded that forecasts appear to be the least understood part of income forecasts.

According to contributors Burgstahler \& Dichev (1997), companies try to prevent earnings management from falling and losing. At the same time, they found that two components of income, cash flow from operations and changes in working capital, were used to generate an increase in profits. They presented two approaches based on the use of heuristics and the theory of prospects of interested parties to motivate to avoid the decline and loss of revenue. In the research paper, Leuz et al. (2003) address systematic differences in earnings management in 31 countries. They propose an explanation for these differences based on the idea that insiders use earnings management to hide their business performance from strangers to protect their private control benefits. Therefore, earnings management is expected to decrease in investor protection, as influential protection limits insiders' ability to gain specific control benefits, reducing their incentive to disguise company performance. It is also important to understand the link between aspects of the business sector and the business environment (Khan et al., 2019). The market, economic and financial risks are the most important risks (Virglerova et al., 2020), which determine the quality and performance of enterprises (Dvorsky et al., 2019).

He et al. (2017) examines the linkage of dividend policy and earnings management and the fact if the mutual bonds between countries changes due to divergent institutional strength or transparency. They point out the payers of dividend tends to manipulate profits less than nondividend payers. This finding is typical of countries with inadequate level of investors' protection and high opaqueness. They also found that dividend payers manage benefits less when they spend capital after dividends are paid. These results are discussed in those national economies where weak institutions and low transparency are observed (Gavurova et al., 2020). 
In a research paper by Beuselinck et al. (2019), they provided valuable information on the drivers for the placement of earnings management within a company. They underlined the need for better coordination between countries in drafting legislation. They analysed a large sample of multinational companies focusing on earnings management within the company. They assumed that multinationals manage their consolidated profits through an organized reporting strategy in subsidiaries over which they have significant influence. The impact of the information system on earnings management was also addressed by Bartov et al. (2017). Specifically based on the notion that the quality of the information system can facilitate and accelerate the preparation of financial statements and decrease revenue management, among other things, by allowing the use of sophisticated software to more effectively prevent earnings manipulation and detect fraud indicators. However, the quality of information system may also enhance the ability of managers to manage and timely modify financial statement information, for instance, due to increased asymmetry of information between managers and external users of financial statements (Sulkowski at el., 2019a).

Beyer et al. (2018) studied earnings management in their publications and provided predictions on time series of earnings characteristics and reporting bias. Based on their results, they estimate that the model empirically separates the two components of investor uncertainty. This is a fundamental economic uncertainty and information asymmetry between manager and investors as a result of reporting noise. Cheng \&Warfield (2003) investigated the links between managers' capital incentives resulting from equity-based compensation and equity ownership and earning management. They assumed that managers with high capital incentives would be more likely to sell shares in the future, which motivated them to engage in revenue management to increase the value of the shares to be sold. Regarding the vital factor limiting earnings management, extensive research suggests that good corporate governance can reduce opportunistic business behaviour, improve the information environment and yield quality. Roychowdhury (2006) focused on finding evidence related to real-life managers to avoid reporting annual losses. In particular, he concentrated on evidence that suggests that sales can be increased temporarily by price discounts, overproduction can results in low costs of sold products, and reported margin can be improved by the reduction in discretionary spending. A cross-sectional analysis indicates that such practices are not common in the presence of cultured investors. Competent advice can discipline top management that follows aggressive earning strategies to manipulate increments, thus eliminating the potential costly external consequences (Hazarika et al., 2012).

Liu \& Lu (2007) confirm that ineffective corporate governance caused by conflicts between significant agents may increase earnings management through tunnelling. Amstrong (2012) suggests the improvement of the information environment, which is reflected in a decline in information asymmetry and an increase in the formalities of the financial statements in the adoption of laws to prevent the takeover, which has an exogenous impact on the corporate control market. Biddle et al. (2009) reveal that enterprises with high level of financial report readability may enjoy better investment efficiency, resulting in greater understanding between enterprises and external suppliers of capital due to elimination of information asymmetry problems. Ding et al. (2007) and Wang et al. (2011) also find that it is typical of listed privateowned enterprises, not of the state-owned ones, that they achieve a higher level of accrual-based earnings management, as private listed companies face a tougher environment for raising capital and minimum state support. Accounting indicators published by firms remain a free source of information for the financial market (Sulkowski et al., 2019b). However, the degree of freedom afforded by accounting policies allows managers to manipulate financial statements at their discretion to mislead stakeholders as to the economic conditions of business (Sayari \& Omri, 2017). Other authors in the field of earnings management are Jona, Filatotchev \& Livne 
(2019), who in their work deal with threats of enforcement by the Securities and Exchange Commission (SEC) and private litigation affecting earnings management in IPO prospectuses. For this analysis, they used a large group of national and international IPOs in America.

The possibilities and areas that earnings management touches are extensive. This is also evidenced by the publication on the relationship between earnings management and time dissociation in the language (Kim, et al., 2017). The paper supposes that business managers are less likely to be engaged in earnings management practices and their perception of earnings manipulation is more immediate, if they operate in those countries where languages do not require speakers to grammatically identify future events. In the literature on earnings management, only modest information was currently found. The previous inquiry has focused almost exclusively on the determination of existence of earnings management phenomenon. The results indicate that there are different incentives and reasons of earnings management, including affecting the perception of the stock market, increasing management compensation, reducing the possibility of breach of credit agreements and preventing regulatory interference (Bin et al., 2018). Some of these results are in line with findings concerning management compensations revealed by Bilan et al. (2020) and Skalicka et al. (2018), but the context of the Muslim culture changes the conditions and results (Qizam, 2021).

Due to the extensive possibilities and areas affected by revenue management, VosViewer was used to analyse earnings management, which the authors have been working on since 1988 to the present. The outputs were divided into decades with the ability to investigate developments.

\section{Methodological approach}

This research paper aims to find out a significant change in the development of the keywords within the earnings management in the time horizon from 1988 to the present. Enterprises react very sensitively to changes in the macro and micro environments which are always reflected in the quantitative features of this sector in a certain period (Hudakova et al., 2018). The field of earnings management was chosen because it is an exciting and modern topic, especially the articles from the Web of Science database. In total, 1,547 articles on earnings management were analysed. The methodology used analysis to assess individual articles, synthesis to link context, statistical measures to choose keywords related to earnings management phenomenon; VOS viewer was used to portray the results of the analysed keywords graphically. VOS viewer is a free downloadable software tool for creating and visualizing bibliometric networks. Within its capabilities allows the analysis of keywords by a given issue and journals, researchers, or individual publications. VOS viewer can be compiled based on citation, bibliographic connection, co-citation, or co-author relations. At the same time, it evaluates this information and can visually distinguish it and divide it into appropriate clusters. It works, for example, with data from Scopus databases or the Web of Science, and efficiently and represents all crucial data with the help of a map. The current paper investigates keywords over decades from 1988 to the present. The analysis of this phenomenon in such a long period allow observing the changes in the perception of earnings management, especially before and after the global economic crisis.

\section{Conducting research and results}

For the first time in history, Hepworth (1953) used the term earnings management. Since then, research into the phenomenon of earnings management (EM) has made significant progress. It is necessary to mention the study by Healy (1985) since the term average total 
accrual was first used to estimate discretionary accruals (DA; discretionary accrual is an optional expenditure, that is yet to be realized, but is already recorded in the books) and hence earnings manipulation. In the becoming years, the authors increasingly dealt with the issue of earnings management. Table 1 summarizes the contributions that significantly influenced the development of research in the field of earnings management (only highly cited articles are evaluated).

Table 1. Breakthroughs in earnings management research

\begin{tabular}{|c|c|c|}
\hline Author & Year & Description \\
\hline McNichols and Wilson & 1988 & Commissions of bad debts \\
\hline Schipper & 1989 & Asymmetry - managers vs shareholders \\
\hline Jones & 1991 & Import concessions concerning EM \\
\hline DeAngelo, DeAngelo and Skinner & 1994 & $\begin{array}{l}\text { The tendency of highly indebted companies to manipulate } \\
\text { profits }\end{array}$ \\
\hline Defond and Jiambalvo & 1994 & Failure to comply with debt contracts \\
\hline Dechow, Sloan and Sweeney & 1995 & Alternative EM detection models \\
\hline Holthausen, Larcker and Sloan & 1995 & Use of economic EM techniques \\
\hline Burgstahler and Dichev & 1997 & The use of EM to avoid profit and loss \\
\hline Teoh, Welch and Wong & 1998 & Reporting of higher net income \\
\hline Healey and Wahlen & 1999 & Definition of EM \\
\hline Degeorge, Patel and Zeckhauser & 1999 & Use EM to bridge negative periods. \\
\hline McNichols & 2000 & $\begin{array}{l}\text { A new approach? Principle of aggregated and specific } \\
\text { accruals, classification of EM }\end{array}$ \\
\hline Peasnell, Pope and Young & 2000 & Cross-sectoral estimation of EM \\
\hline Yoon and Miller & 2002 & Effect of operating discretionary accrual performance \\
\hline Skinner and Sloan & 2002 & Distortion the real business image \\
\hline Klein & 2002 & Nature and significance of auditors \\
\hline Xie, Davidson and DeDalt & 2003 & $\begin{array}{l}\text { The role of the company's administration board in EM } \\
\text { prevention. }\end{array}$ \\
\hline Leuz, Nanda and Wysocki & 2003 & Investor protection research \\
\hline Burgstahler, Hail and Leuz & 2006 & EM's relation to the capital market \\
\hline Roychowdhury & 2006 & Manipulation by economic activity \\
\hline $\mathrm{Ye}$ & 2007 & Cross-sectional view and time series of EM models \\
\hline Jeanjean and Stolowy & 2008 & Impact of IFRS Standards on EM \\
\hline Yague et al. & 2009 & Changes in market prices of shares and EM \\
\hline Callao and Jarne & 2010 & Effect of IFRS on EM \\
\hline Barth and Taylor & 2010 & Securitization of EM assets \\
\hline Chen et al. & 2010 & Sophisticated investors and EM \\
\hline Nwaeze & 2011 & EM motives and incentives \\
\hline Okamoto & 2011 & Collective intent and EM \\
\hline Rodrigues, Marques and Craig & 2011 & EM caused by corporate tax policy \\
\hline Alhadab, Clacher and Keasey & 2015 & Activities EM and risk public offer of shares \\
\hline Cimini & 2015 & The 2008 financial crisis and its impact on EM \\
\hline Kothari, Mizik and Roychowdhury & 2015 & EM and the value of corporate shares \\
\hline Collins, Pungaliya and Vijh & 2016 & Effect of enterprise growth on EM \\
\hline Lo, Ramos and Rogo & 2017 & EM and transparency of annual statements \\
\hline
\end{tabular}

Source: own research

The latest knowledge in this area focuses on various problems, but the authors usually try to uncover the motives and incentives for manipulating the profits. Brandau et al. (2014) and $\mathrm{Li}$ et al. (2014) emphasize the importance of managerial accounting in emerging and developed countries. Similar findings are typical for investigation of influence of changes in accounting regime on improvement in earnings quality in listed firms (Hoang \& Joseph, 2019). Other researchers pay attention to both accrual-based earnings management and real activities 
manipulations rather than to separated earnings management strategy (Khanh \& Thu, 2019). Ding et al. (2018) suggest that political affiliates are more likely to engage in profitmanipulating activities than non-affiliated enterprises. Elleuch Hamza \& Kortas (2019) examine the link between accounting revenue management and manipulating real economic activities. Campa's findings (2019) reveal more widespread use of earnings manipulation by increasing returns among listed companies compared to unlisted entities. The interdependence between an environment of social confidence and security and earnings management described by Chen et al. (2019).

A specific area consists of models and researches of earnings management in European countries. There is also a wide range of areas that the authors explore within the phenomenon of earnings management. Wrobleski (2016) points out that, over the past 20 years, only a few studies carried out to map the profitability of management in specific business conditions.

To analyse articles dealing with earnings management, only materials from the Web of Science database were refined; and only those articles were considered that incorporate earnings management in the title. To ensure the most relevant results by filtering out non-related articles, allowed to gain the total number of 1547 articles. The picture shows a growing trend in the publication of articles dealing with earnings management (Fig. 1). It should be borne in mind that the number of publications in the WOS database is influenced by more than just the topicality of the issue.

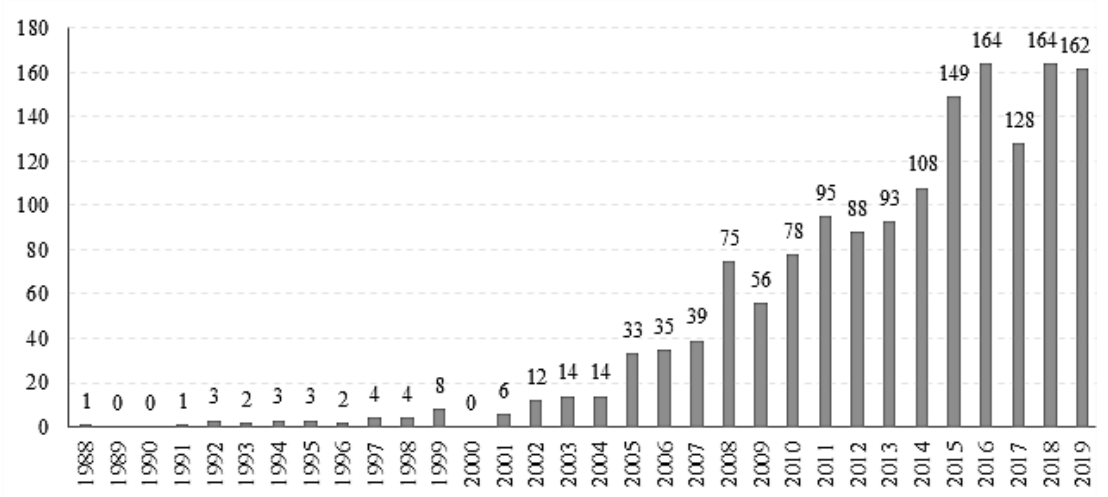

Figure 1. Number of publications on earnings management in WoS

Source: own research

The main reason for the increase is the worldwide increase in the number of publications registered in scientific databases, due to changes in the criteria in the evaluation of academic personnel. Universities, as well as their staff, are increasingly rated based on the number of publications in scientific databases. One of the most renowned databases is the Web of Science. Another factor influencing the development of the publication is the global situation. The interest in earnings manipulation, as well as im many other financial themes, encountered a sharp increase in 2008 of almost 100\%. The year 2008 was in the name of the global financial crisis (Tulyakova et al., 2019). Balcerzak, et al. (2017). Earnings management appeared more and more frequently in articles after this year. Since 2016, a steady number of publications at around 160 articles per year can be observed, which is due to a constant number of scientists working on this issue.

The publications on earnings management were filtered (1.547 pcs.) and divided into four groups, according to time. The main goal is to find out how the perception of earnings management has evolved, and thus the keywords from the articles were analysed in the VOS viewer and saw how their relationships and numbers changed. The first group analysed 
contained articles published between 1988 and 1997. A total of 34 keywords were used in these articles. Setting the rule to have a keyword in at least three articles reduced the number of keywords to 3 (Fig. 2). Accruals were most often associated with keyword earnings management. This suggests that earnings management was mainly associated with cost and income management over time. The second cluster contains keyword decisions. This points to managerial decision making when working with profit. The low number of keywords is due to the small number of publications in this period.

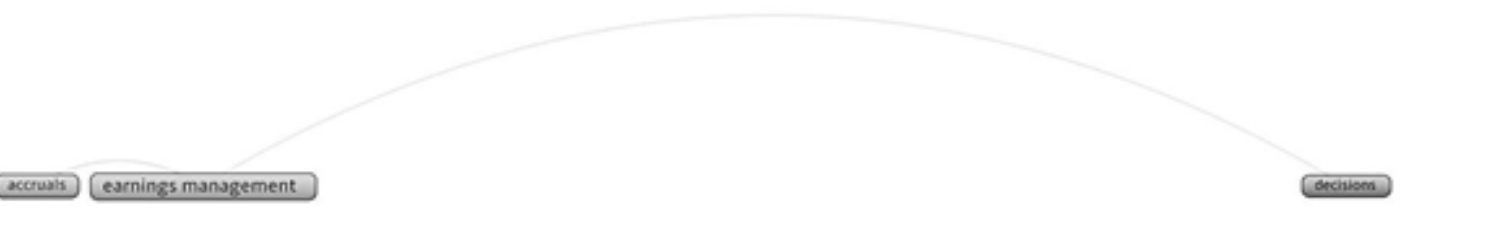

Figure 2. Keyword analysis for $1988-1997$

Source: own research

The second group analysed contained articles published between 1998 and 2007. In total, these articles included 467 keywords. By setting the keyword to appear in at least ten publications, 13 most common keywords left organized in a single cluster (Fig. 3). Compared to the previous period, the following keywords were added: bonus schemes, corporate governance, decisions, discretionary accruals, firms, income, information, losses, ownership, performance and seasoned equity offerings. Earnings management was most often associated with performance. During this period, several articles focused on improving business performance with the help of earnings management. The two periods analysed had in common that they were from before the economic crisis.

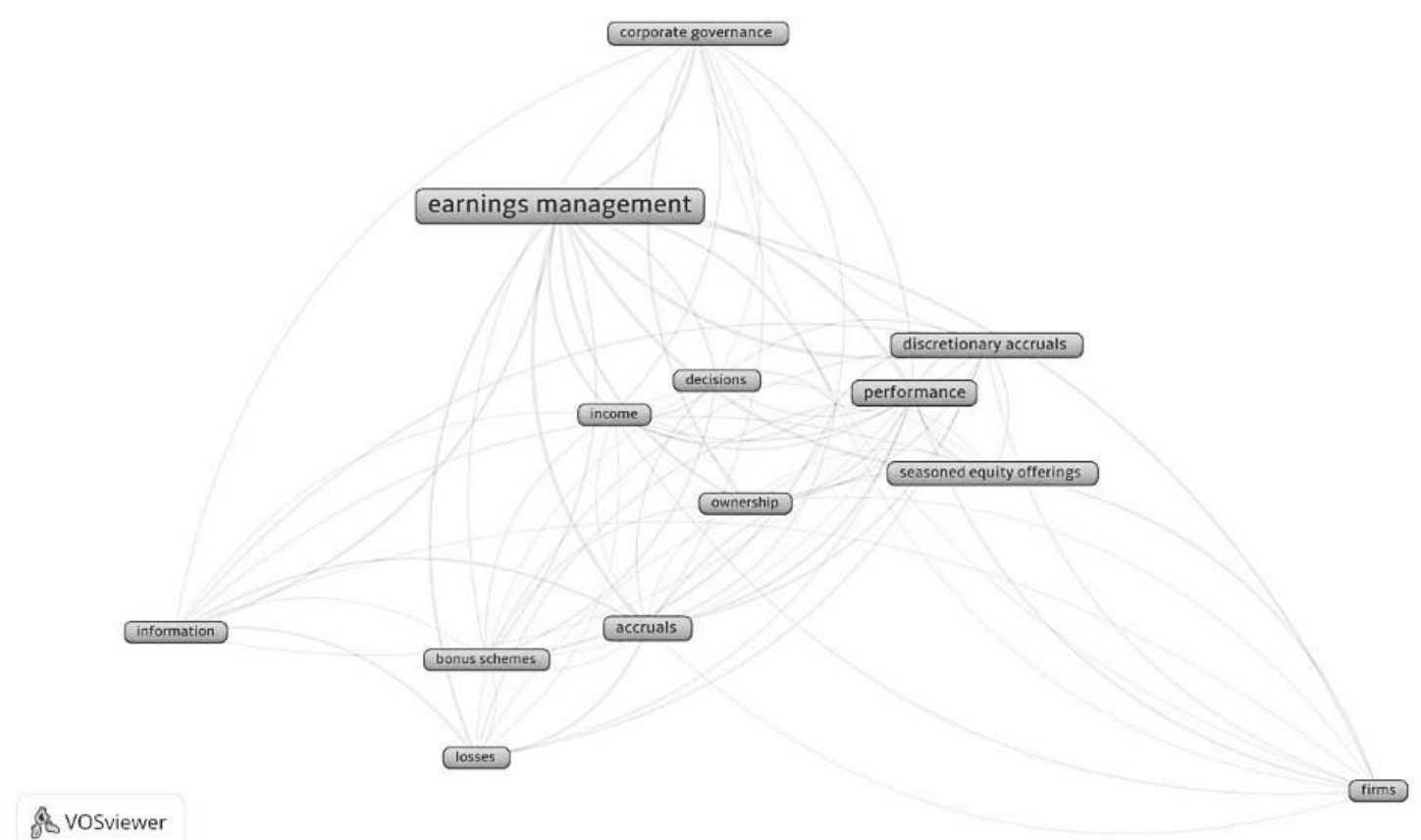

Figure 3. Bibliometric analysis for $1998-2007$

Source: own research 
The third group consists of articles published in the years 2008-2017, which was the post-economic crisis period. During this period, earnings management has seen an increase over the previous two periods. The issue of earnings management has become more desirable, and several researchers in the field of economics have begun to address it during this period. In recent years, researchers have been trying to define conditions that could guarantee stability (Kocisova, et al., 2018). In total, 2.437 keywords were found in earnings management publications from that period. To get to the most important ones, it was determined that they should be present in at least 30 publications.

After this selection, 35 main keywords were identified (Fig. 4). Compared to the period before the economic crisis, new keywords were added as accounting standards, accruals, association, audit committee, audit quality, behaviour, board, bonus schemes, consequences, corporate governance, determinants, disclosure, earnings, earnings quality, firm, firm performance, firms, china, IFRS, incentives, income, information, initial public offerings, investment, investor protection, losses, manipulation, ownership, ownership structure, real activities handling, real earnings management, risk, seasoned equity offers and valuation. The concepts of corporate governance and investor protection were most closely associated with the theme of earnings management.

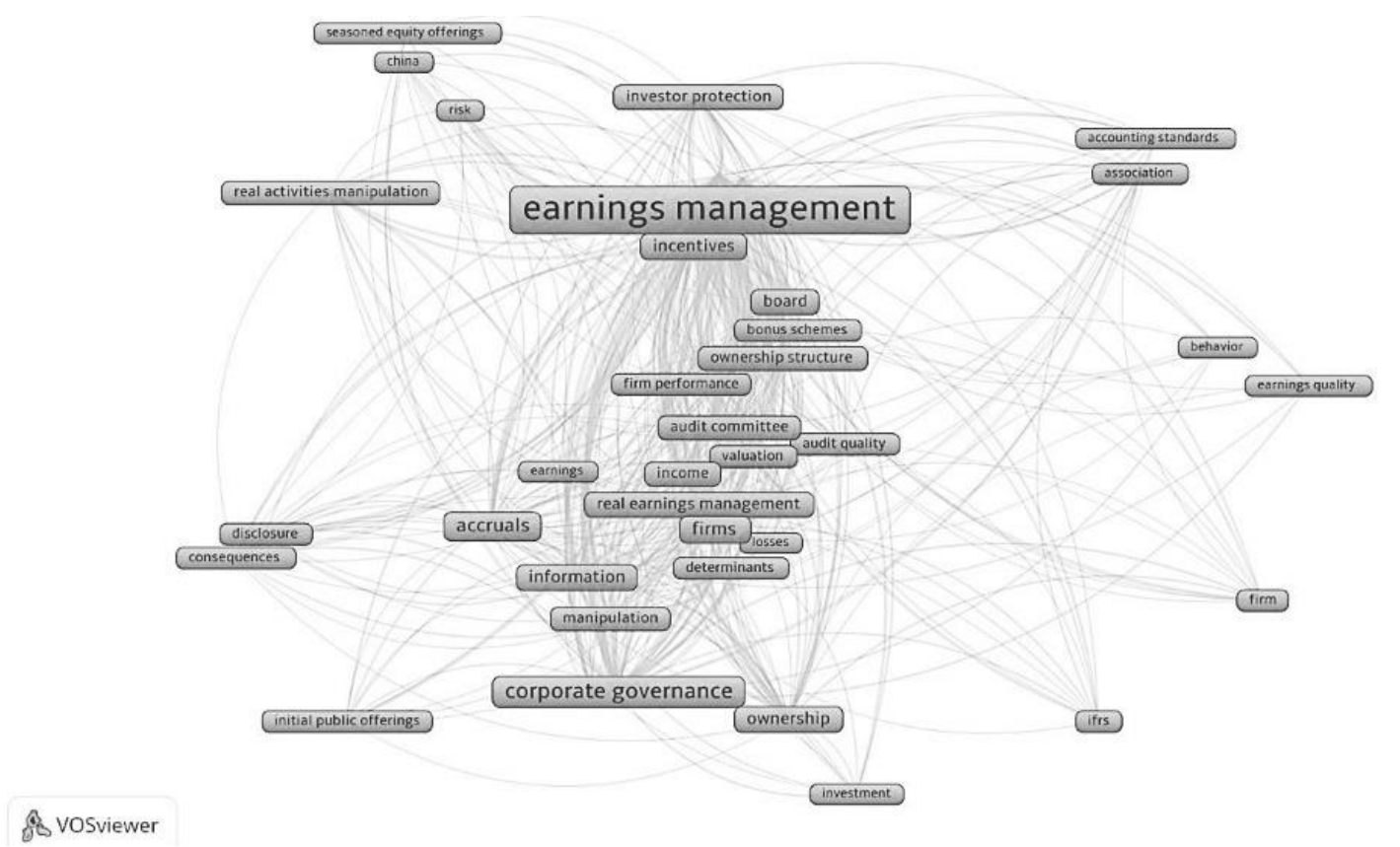

Figure 4. Bibliometric analysis for $2008-2017$

Source: own research

The last analysed period is from 2018 to the end of 2019. This group is smaller compared to the previous groups, where the data for ten years were analysed. It is essential to include it in the analysis because of the increase in the number of publications in recent years. A total of 1.256 keywords were used in publications during this period, but only 31 words appeared in at least ten publications (Fig. 5). 
\& vosviewer

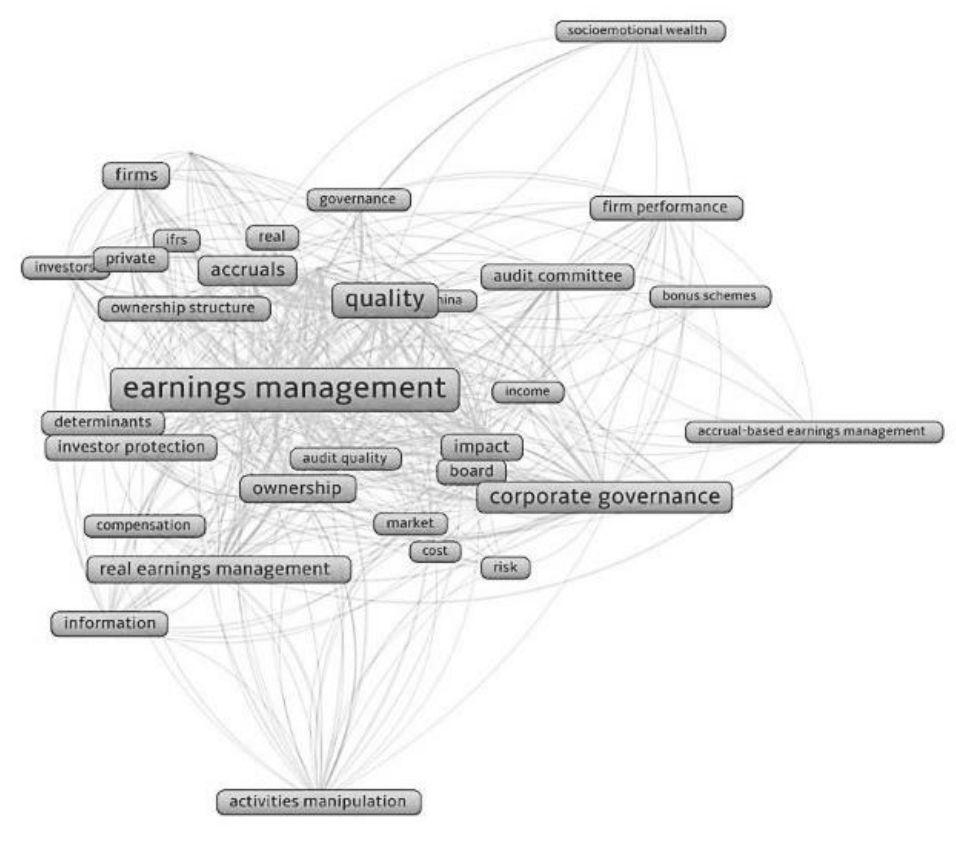

Figure 5. Bibliometric analysis for 2018 - present

Source: own research

In comparison with the previous group, the articles started to show more keywords such as accrual-based earnings management, accruals, activities manipulation, audit committee, audit quality, board, bonus schemes, compensation, corporate governance, cost, determinants, firm performance, firms, governance, China, IFRS, impact, income, information, investor protection, investors, market, ownership, ownership structure, private, quality, real earnings management, risk, socioemotional wealth. In these years, earnings management was most often associated with the concept of quality and corporate governance.

\section{Conclusion}

The paper pointed out that the perception, as well as the application of earnings management, has changed in the specific reporting periods. The terms that were most commonly associated with earnings management continued to expand, but the primary group of words remained unchanged. Global trends in economic and finance have influenced the perception of earnings management phenomenon and thus the number of publications in the international context has increased. However, the importance of accrual, discretionary and nondiscretionary, is associated with earnings management in each analysed time interval. The identification of the most used and analysed term related to earnings management, contributes to the fulfilment of the stated purpose of the paper.

In the future, the upcoming trends should be analysed especially in the context of deep recession caused by the COVID-19 pandemic - to see changes in the application of earnings management behaviour in the corporate practice. This article can be further used as a theoretical basis for the investigation of new relationships, relationships and structures in the solved problems. It makes it possible to better understand the development and perception of earnings management over time and is a good starting point for further studies. 


\section{Acknowledgement}

This paper was supported by the Slovak Research and Development Agency under Grant number APVV-17-0546: Variant Comprehensive Model of Earnings Management in Conditions of the Slovak Republic as an Essential Instrument of Market Uncertainty Reduction.

\section{References}

Acemoglu, D., Johnson, S., Robinson. I., \& Thaicharoen, Y. (2004). Institutional Causes. Macroeconomic Symptoms: Volatility. Crises and Growth. Journal of Monetary Economics, 50, 49-123.

Alhadab, M., Clacher, I., \& Keasey, K. (2015). Real and accrual earnings management and IPO failure risk. Accounting and Business Research, 45(1), 55-92.

Amstrong, M. (2012). Amstrongs handbook of reward management practice. Improving Performance through Reward, 4th ed.; Kogan Page: London, UK.

Balcerzak, A. P., Kliestik, T., Streimikiene, D., \& Smrcka, L. (2017). Non-parametric approach to measuring the efficiency of banking sectors in European Union Countries. Acta Polytechnica Hungarica, 14(7), 51-70.

Barth, M., \& Taylor, D. (2010). In defence of fair value: Weighing the evidence on earnings management and asset securitizations. Journal of Accounting and Economics, 49(1-2), 26-33.

Bartov, E., Marra, A., Dossi, A., \& Pettinicchio, A. K. (2017). Earnings management, timeliness, and corporate information systems. Timeliness, and Corporate Information Systems (June 20, 2017).

Belas, J., Gavurova, B., \& Toth, P. (2018). Impact of selected characteristics of SMES on the capital structure. Journal of Business Economics and Management, 19(4), 592-608.

Beneish, M. D. (2001). Earnings management: A perspective. Managerial Finance, 27(12), 317.

Beuselinck, C., Cascino, S., Deloof, M., \& Vanstraelen, A. (2018). Earnings management within multinational corporations. The Accounting Review.

Beyer, A., Guttman, I., \& Marinovic, I. (2018). Earnings management and earnings quality: Theory and evidence. The Accounting Review, 94(4), 77-101.

Biddle, G. C., Hilary, G., \& Verdi, R. S. (2009). How does financial reporting quality relate to investment efficiency?. Journal of accounting and economics, 48(2-3), 112-131.

Bilan, Y., Mishchuk, H., Samoliuk, N., \& Mishchuk, V. (2020). Gender discrimination and its links with compensations and benefits practices in enterprises. Entrepreneurial Business and Economics Review, 8(3), 189-204. https://doi.org/10.15678/EBER.2020.080311

Bin, L., Chen, D. H., \& Hasanatunnisa, S. (2018). The earnings-return association of family and non-family Indonesian firms: an empirical study. Economics, Management \& Financial Markets, 13(2).

Burgstahler, D. C., Hail, L., \& Leuz, C. (2006). The importance of reporting incentives: Earnings management in European private and public firms. The accounting review, 81(5), 983-1016.

Burgstahler, D., \& Dichev, I. (1997). Earnings management to avoid earnings decreases and losses. Journal of accounting and economics, 24(1), 99-126

Callao, S., \& Jarne, J. I. (2010). Have IFRS affected earnings management in the European Union? Accounting in Europe, 7(2), 159-189. 
Chen, S. K., Lin, B. X., Wang, Y., \& Wu, L. (2010). The frequency and magnitude of earnings management: Time-series and multi-threshold comparisons. International Review of Economics \& Finance, 19(4), 671-685.

Cheng, Q., \& Warfield, T. D. (2005). Equity incentives and earnings management. The accounting review, 80(2), 441-476.

Cimini, R. (2015). How has the financial crisis affected earnings management? A European study. Applied economics, 47(3), 302-317.

Collins, D. W., Pungaliya, R. S., \& Vijh, A. M. (2016). The effects of firm growth and model specification choices on tests of earnings management in quarterly settings. The Accounting Review, 92(2), 69-100.

DeAngelo, H., DeAngelo, L., \& Skinner, D. J. (1994). Accounting choice in troubled companies. Journal of accounting and economics, 17(1-2), 113-143.

Dechow, P. M., \& Sloan, R. G. (1995). Sweeney. Detecting earnings management, 70(2). 193225.

DeFond, M. L., \& Jiambalvo, J. (1994). Debt covenant violation and manipulation of accruals. Journal of accounting and economics, 17(1-2), 145-176.

Degeorge, F., Patel, J., \& Zeckhauser, R. (1999). Earnings management to exceed thresholds. The Journal of Business, 72(1), 1-33.

Ding, Y., Zhang, H., \& Zhang, J. (2007). Private vs state ownership and earnings management: evidence from Chinese listed companies. Corporate Governance: An International Review, 15(2), 223-238.

Dvorsky, J., Petrakova, Z., \& Polach, J. (2019). Assessing the Market, Financial, and Economic Risk Sources by Czech and Slovak SMEs. International Journal of Entrepreneurial Knowledge, 7(2), 30-40.

Fialova, V., \& Folvarcna, A. (2020). Default prediction using neural networks for enterprises from the post-soviet country. Ekonomicko-manazerske spektrum, 14(1), 43-51.

Gavurova, B., Ivankova, V., Rigelsky, M., \& Privarova, M. (2020). Relations between tourism spending and global competitiveness - an empirical study in developed OECD countires. Journal of Tourism and Services, 21(11), 38-54. https://doi.org/10.29036/jotc.v11i21.175

Grofcikova, J. (2020). Impact of selected determinants of corporate governance on financial performance of companies, Ekonomicko-manazerske spektrum, 14(2), 12-23.

Hardingham, E., Vrbka, J., Kliestik, T., \& Kliestikova, J. (2018). Will Cognitive TechnologyDriven Automation Lead to Economic Growth? Journal of Self-Governance and Management Economics, 6(4), 13.

Hazarika, S., Karpoff, J. M., \& Nahata, R. (2012). Internal corporate governance, CEO turnover, and earnings management. Journal of Financial Economics, 104(1), 44-69.

He, W., Ng, L., Zaiats, N., \& Zhang, B. (2017). Dividend policy and earnings management across countries. Journal of Corporate Finance, 42, 267-286.

Healy, P. M. (1985). The effect of bonus schemes on accounting decisions. Journal of accounting and economics, 7(1-3), 85-107.

Healy, P. M., \& Wahlen, J. M. (1999). A review of the earnings management literature and its implications for standard setting. Accounting horizons, 13(4), 365-383.

Hepworth, S. R. (1953). Smoothing periodic income. The Accounting Review, 28(1), 32-39.

Hirst, D. E., Koonce, L., \&Venkataraman, S. (2008). Management earnings forecasts: A review and framework. Accounting horizons, 22(3), 315-338.

Hoang, T. C., \& Joseph, D.M. (2019). The effect of new corporate accounting regime on earnings management: Evidence from Vietnam. Journal of International Studies, 12(1), 93-104. doi:10.14254/2071-8330.2019/12-1/6 
Holthausen, R. W., Larcker, D. F., \& Sloan, R. G. (1995). Annual bonus schemes and the manipulation of earnings. Journal of accounting and economics, 19(1), 29-74.

Hudakova, M., Masar, M., Luskova, M., \& Patak M.R. (2018). The Dependence of Perceived Business Risks on the Size of SMEs. Journal of Competitiveness, 10(4), 54-69.

Jeanjean, T., \& Stolowy, H. (2008). Do accounting standards matter? An exploratory analysis of earnings management before and after IFRS adoption. Journal of accounting and public policy, 27(6), 480-494.

Jona, J., Filatotchev, I., \& Livne, G. (2019). Earnings Management in Domestic and Foreign IPOs in the United States: Do Home Country Institutions Matter?

Jones, J. J. (1991). Earnings management during import relief investigations. Journal of accounting research, 29(2), 193-228.

Kim, J., Kim, Y., \& Zhou, J. (2017). Languages and earnings management. Journal of Accounting and Economics, 63(2-3), 288-306.

Klein, A. (2002). Audit committee, board of director characteristics, and earnings management. Journal of accounting and economics, 33(3), 375-400.

Kocisova, K., Gavurova, B., \& Behun, M. (2018). The evaluation of stability of Czech and Slovak banks. Oeconomia Copernicana, 9(2), 205-223.

Khan, K. A., Çera, G., \& Netek, V. (2019). Perception of the selected business environment aspects by service firms. Journal of Tourism and Services, 10(19), 111-127.-127.

Khanh, M.T.H, \& Thu, P. A. (2019). The effect of financial leverage on real and accrual-based earnings management in Vietnamese firms. Economics and Sociology, 12(4), 299-312. doi:10.14254/2071-789X.2019/12-4/18

Kothari, S. P., Mizik, N., \& Roychowdhury, S. (2015). Managing for the moment: The role of earnings management via real activities versus accruals in SEO valuation. The Accounting Review, 91(2), 559-586.

Kramarova, K., Gregova, E., \& Cisko, S. (2014). Changes in the corporate tax in Slovakia-tax license. Business and management, 597-603.

Leuz, C., Nanda, D., \& Wysocki, P. D. (2003). Earnings management and investor protection: an international comparison. Journal of financial economics, 69(3), 505-527.

Liu, Q., \& Lu, Z. J. (2007). Corporate governance and earnings management in the Chinese listed companies: A tunneling perspective. Journal of Corporate Finance, 13(5), 881906.

Lo, K., Ramos, F., \& Rogo, R. (2017). Earnings management and annual report readability. Journal of Accounting and Economics, 63(1), 1-25.

Marques, M., Rodrigues, L. L., \& Craig, R. (2011). Earnings management induced by tax planning: The case of Portuguese private firms. Journal of International Accounting, Auditing and Taxation, 20(2), 83-96.

McNichols, M. F. (2000). Research design issues in earnings management studies. Journal of accounting and public policy, 19(4-5), 313-345.

McNichols, M., \& Wilson, G. P. (1988). Evidence of earnings management from the provision for bad debts. Journal of accounting research, 1-31

Nwaeze, E. T. (2011). Are incentives for earnings management reflected in the ERC: Large sample evidence. Advances in Accounting, 27(1), 26-38.

Okamoto, N. (2011). Collective intentionality and aggressive earnings management: Developing Norman Macintosh's arguments in the debate over principles-versus rulesbased accounting standards. Critical Perspectives on Accounting, 22(2), 236-242.

Peasnell, K. V., Pope, P. F., \& Young, S. (2000). Detecting earnings management using crosssectional abnormal accruals models. Accounting and Business research, 30(4), 313-326. 
Qizam, I. (2021). Do sukuk ratings non-contingently affect stock returns? Evidence from Indonesia and Malaysia. Entrepreneurial Business and Economics Review, 9(1), 137-153. https://doi.org/10.15678/EBER.2021.010109

Roychowdhury, S. (2006). Earnings management through real activities manipulation. Journal of accounting and economics, 42(3), 335-370.

Salaga, J., Bartosova, V., \& Kicova, E. (2015). Economic Value Added as a measurement tool of financial performance. Procedia Economics and Finance, 26, 484-489.

Sayari, S., \& Omri, A. (2017). Earnings management, accruals and stock liquidity. The Journal of Finance, 5(1), 17-28.

Schipper, K. (1989). Earnings management. Accounting horizons, 3(4), 91-102.

Skalická, M., Zinecker, M., Balcerzak, A., \& Meluzín, T. (2018). Why Do Companies Go Public? Evidence from the Prague Stock Exchange. Entrepreneurial Business and Economics Review, 7(1), 151-199. https://doi.org/10.15678/EBER.2019.070110

Skinner, D. J., \& Sloan, R. G. (2002). Earnings surprises, growth expectations, and stock returns or don't let an earnings torpedo sink your portfolio. Review of accounting studies, 7(2-3), 289-312.

Sosnowski, T. (2018). Earnings management in the private equity divestment process on Warsaw Stock Exchange. Equilibrium. Quarterly Journal of Economics and Economic Policy, 13(4), 689-705.

Sułkowski, Ł., Seliga, R., \& Wozniak, A. (2019a). From Coopetition by Cooperation to Consolidation. Contemporary. In Contemporary Challenges in Cooperation and Coopetition in the Age of Industry 4.0: 10th Conference on Management of Organizations' Development (MOD) (p. 175). Springer Nature.

Sulkowski, L., Wozniak, A., \& Seliga, R. (2019b). Organizational identity of university in merger process. Economic and Social Development: Book of Proceedings, 756-762.

Teoh, S. H., Welch, I., \& Wong, T. J. (1998). Earnings management and the underperformance of seasoned equity offerings. Journal of Financial economics, 50(1), 63-99.

Tulyakova, I.R., Dengov, V.V., \& Gregova, E. (2019). The position of Russia and Croatia shipbuilding products on world markets and prospects of cooperation (analytical review). Naše More, 66(3), 112-119.

Virglerova, Z., Conte, F., Amoah, J., \& Massaro, M. R. (2020). The perception of legal risk and its impact on the business of SMEs. International Journal of Entrepreneurial Knowledge, 8 (2), 1-13. http://dx.doi.org/10.37335/ijek.v8i2.115

Wang, J. L., Sheu, H. J., \& Chung, H. (2011). Corporate governance reform and earnings management. Investment Management and Financial Innovations, 8(4), 109-118.

Xie, B., Davidson III, W. N., \& DaDalt, P. J. (2003). Earnings management and corporate governance: the role of the board and the audit committee. Journal of corporate finance, $9(3), 295-316$.

Yagüe, J., Gómez-Sala, J. C., \& Poveda-Fuentes, F. (2009). Stock split size, signaling and earnings management: Evidence from the Spanish market. Global Finance Journal, 20(1), 31-47.

Ye, J. (2007). Accounting accruals and tests of earnings management. Available at SSRN 1003101.

Yoon, S. S., \& Miller, G. (2002). Earnings management of seasoned equity offering firms in Korea. The international journal of accounting, 37(1), 57-78. 